\title{
The subject as totum potestativum in Albert the Great's Fuvre: cultural transfer and relational identity
}

\section{Introduction}

When Albert the Great comments on the eleventh proposition of the Liber de causis, an anonymous tractate that had probably been composed in Baghdad in the ninth century in the circle of the Neoplatonic philosopher Al-Kindi and that had been translated into Latin in the twelfth century in Toledo, he is confronted with a theory of identity that questions the Aristotelian conception of the subject as a substance. According to the theory of identity in the Liber de causis, the first metaphysical principles, which are substances such as Being, Life and Intelligence, are not only defined by what they are in themselves but also by what they are in their causes and by what they are in their effects. So is it as well the case, according to the Liber de causis, of the soul and its faculties: the vegetative, sensitive and intellective ones. Their identity is not only to be conceived of as substantial (what they are in themselves), but also as relational (what they are in relation with others).

The cultural transfer of Neoplatonic Greek-Arabic metaphysics into the Latin world entails a change of paradigm in the idea of the individual as an isolated substance that constitutes an indivisible entity. Instead of conceiving of the identity as a substance in an atomic and static way, the Albertian appropriation of the Liber de causis theory offers a dynamic and relational conception of individual identity: far from excluding what is different from it, this conception includes it. This individual identity is, therefore, to be conceived of as a totality with what is different from its substance. Such a totality includes what is different from the individual substrate and is reciprocally included in it.

This dynamic and relational conception of the identity of the subject was not unfamiliar to the Middle Ages. The Greek and Latin Fathers of the Church had already applied the model of the perichôresis, or circumincessio, to conceive of the psycho-theological homology of the soul and its faculties with the divine persons, as they are described in the Gospel of John (for instance, in Jn 10:38 and 14:10): the Father is in the Son and the Son in the Father. And, in his De trinitate (Augustinus Hipponensis 1968, 330, 29-331, 60-3), Augustine takes up this inheritance and conceives of the human soul as identical not exactly with its own substance but with the operations of its faculties: memory, will and intelligence. The soul does 
not lie, therefore, under its operations, like a substratum. As a principle of life, the soul expresses itself through its faculties in different ways. These various modes of expression form, in return, the interiority of the soul. As in a Möbius strip, the inner and the outer are in the soul as a single act, a unique identity.

However, Alain de Libera, in his Archéologie du Sujet (Libera 2007, 287), asserts that this dynamic and relational model of the identity of the subject has only temporarily offered an alternative model to what he calls 'attributivismus': that is, the Aristotelian conception of the subject that the Middle Ages inherits. The 'attributivismus' model refers to the identity of the subject defined by the attribution of properties (qualities and faculties) to an individual substrate. According to Alain de Libera, soon the dominant conception of the subject as a substratum to which properties are attributed has annexed the Augustinian model according to which the identity of the subject includes differences and reveals itself through them.

In this paper, I would like to show, firstly, that Albert the Great introduces the categories of potentiality and relation into the conception of substantial identity inherited from the 'attributivismus' model. To do so, he appeals to the Boethian totum potestativum. Secondly, I would like to highlight that he is not completely satisfied with the Boethian attempt to conceive of a dynamic and relational identity. Especially, the hierarchical characteristic of the Boethian totum potestativum fails, according to him, to provide the means to think of a dynamic and relational totality in which the different powers are, simultaneously and reciprocally, in each other. However, Albert the Great finds this reciprocity in the Liber de causis.

\section{Is the soul identical to its faculties?}

The 'attributivismus' model appears in the conception of the soul that Albert the Great develops, in particular in his commentaries on the Aristotelian tractates (Anzulewicz 2012, 325-46) and in his anthropological synthesis De homine. But this conception, which is elaborated in a physical and anthropological frame, is put into question when it is transferred to a theological field. To expose the Albertian conception of the 'attributivismus' pattern of the identity of the soul as a substratum, I shall concentrate my attention on one of the texts in which the Master of Cologne contrasts it to an alternative model using the concept of totum potestativum. In their article upon totality in Albert's Euvre, Katja Krause and Henryk Anzulewicz, leaning on Pius Künzle and Dag Nikolaus Hasse (Schneider 1903; 1906, vol. 1, 35, 38-40; vol. 2, 521f.; Künzle 1956, 43-158; Park 1980, 506-8; Hasse 2008, 236f.; Müller 2009, 194-203; Hellmeier 2011, 66-9, 75f., 105f., 
117, 131f., 152f., 233f., 298, 311, 313f.; Krause, Anzulewicz 2017, 116; Mahoney 1980, 551f.), see in these two models of anthropologic identity (Albertus Magnus 2008, 4, 38; 17, 65; 27, 26; Albertus Magnus 1968, 1, 7-3; 1, 20; Anzulewicz 2012, 336; Anzulewicz 2000, 149, n. 4) a compatibility. For my part, I shall defend a reading of Albert's commentary on the first book of Peter Lombard's Sentences, highlighting the difference in the dynamics of what I consider as two distinct perspectives on the human soul. If one can speak about compatibility, it is then, in my eyes, in the same way as a cubist figure assembles on the unique plane of a painting several points of view that the spectator normally cannot see simultaneously. I propose to distinguish these perspectives on the human soul as different modes of being. They exist at the same time and concern the same subject but they describe different dynamics in which the human soul develops itself.

\section{1 'Attributivismus' model and totum potestativum}

First of all, let us show how the 'attributivismus' and the totum potestativum models are different perspectives on the identity of the same individual subject and, more precisely in this case, on the human soul. In 'distinction 3' of his commentary on the first book of the Sentences (Albertus Magnus 2015, 113, 9-22), Albertus Theutonicus asserts that the soul is not identical to its vegetative, sensitive and intellectual powers. Those are only its properties. Albert develops the difference between the identity of the soul as a spiritual substance and its identity as a totality of powers in the following way.

Either the faculties of the soul follow the soul considered as a spiritual substance - that is they are consequences of the soul, which is regarded as their principle - or they belong to its substance, if the soul is considered as a substance acting upon the body and upon what is external to the soul (Hasse 2008, 237f.). Only under this second perspective, the soul is understood as a totum potestativum, that is, as a whole susceptible of powers, which are the vegetative, sensitive and intellectual faculties of the soul. This means that the soul, as a totality of powers, achieves itself in and through its vegetative, sensitive and intellectual faculties, when these are understood as properties of the soul and not as consequences of it. Therefore, the complete power of the soul is composed by the particular powers of its faculties. That is why they are called substantial properties of the soul which would not, without them, find the fulfilment of its own possibility of being.

So, on the basis of the distinction between the logical status of 'consequence' and of 'substantial property' that is attributed to the faculties of the soul, it appears clearly that the two patterns of conceiving of the soul are incompatible: the powers of the soul are consequences of a spiritual substance, according to 
the 'attributivismus' pattern, whereas they are substantial to the soul when conceived as a totum potestativum. The identity of the human soul can be described according to both patterns: the 'attributivismus' one and the totum potestativum. But each of them expresses a singular mode of being of the human soul and highlights different dynamics in which the human soul develops its own identity.

Secondly, Albert of Cologne demonstrates that neither according to the 'attributivismus' model nor according to the non-attributivismus pattern, the human soul can be identified only to its faculties. Let us, first, concentrate our attention on the 'non-attributivismus' model of the identity of the soul and show how Albert emphasises its potentiality and relationality. We will take up the name that he gives to it: a totum potestativum. Albert's conception of the identity of a whole of powers, or dynamic whole, consists in describing the potentiality of a totality. Let us précis Albert's arguments. A totum potestativum does not point out the nature of the soul as a spiritual substance but as an acting substance. It is, therefore, a dynamic pattern of identity. Albert argues that the identity that is proper to the 'non-attributivismus' model is not essential but potential. In other words, the identity of the totum potestativum does not describe the attribution of properties to an essence which would be in itself sufficient to define the identity of a being. He gives a theological reason for it: the soul is not essentially what it has, that is its faculties, since only God is what He has (Albertus Magnus 2015, $112,58-60)$. But the identity of the totum potestativum intends to describe the potentiality of a totality and to stress how much the soul is present to its faculties and develops itself through them.

More precisely, when we say 'the soul is its faculties', for instance its senses, we attribute the totum potestativum as a predicate to the faculty to which the soul is present. In other words, it is true that 'the soul is its senses' only when it perceives. Moreover, this limitation of the identification of the soul, as a dynamic whole, to its faculties is reinforced by the different degrees of presence of the soul to its faculties. There is, namely, a hierarchical identification of the whole to its parts according to the level that each part - vegetative, sensitive or intellective - occupies in the constitution and in the action of the soul. The soul can be either incompletely or completely present to its different faculties: the power of the soul, its posse, is incompletely in the inferior faculties, that is to say the vegetative and the sensitive parts of the soul, and completely in the superior ones, the intellective part. The soul is completely present to the superior power, because the activity of the intellect always presupposes the power of the inferior parts. But even if the proposition 'the soul is its intellect', that is the predication of the soul to the superior part, is more adequate than its predication to the inferior parts, nevertheless, it is not a completely appropriate predication (ibid., 113, 23-33), because it is not an essential predication of an attribute to its subject, but 
a potential and hierarchical predication of different powers to an active whole that develops them. Therefore, it is never possible to say properly that the soul is its faculties, because they are either consequential properties of a spiritual substance, according to the 'attributivismus' model, or powers of an active whole to which the soul is more or less completely present, according to the totum potestativum pattern. Moreover, according to the totum potestativum model, the mode of predication is only potential, and not essential.

Thirdly, from the point of view of categories, these two conceptions of identity are not compatible. They are different points of view on the same being and they define its identity according to different perspectives (ibid., 113, 36-8). The 'non-attributivismus' model introduces, thus, not only a dynamic perspective on identity but also a consideration on its potentiality, that is, on its possibility to act and to develop its powers. It is a model of identity concentrated on what a being, taken as a whole, can become through its action more than on what it is according to its essence, or nature. Yet, posse, or the possibility to act and to become, belongs to the category of quality, whereas esse, or being, pertains to the quality of substance (ibid., 112, 63). As a consequence, the 'non-attributivismus' model differs from the 'attributivismus' one also from a categorical point of view: it considers identity under the category of quality, and not of substance. The question that the totum potestativum raises is not, therefore, 'what is this being as a nature?' but 'which quality can a being acquire through the development of its powers?'; 'which possibilities do its faculties endow it through their action?'. Thus, we understand that, even if the 'attributivismus' and 'non-attributivismus' models are not compatible, yet, they can be understood as different categorical points of view on the identity of a being. The qualitative point of view considers the possible becoming of a being as a whole that develops itself through its powers. The substantial point of view takes a being as an individual defined by a nature, that is a genus determined by a species, and considers its properties.

For example, if we say that the powers of the soul - which are its memory, its will, its intelligence - are the soul itself (Pseudo-Augustinus 1845, 789; Alexander de Hales 1960, 64, 15-17; Bernardus Claraevallensis 1957, 57, 18f.; Albertus Magnus 2015, 113, 1-8), we identify the faculties, taken together, to the soul only as far as we consider here the soul as a totality constituted of parts endowed with powers. In no way are the faculties identified to the soul according to its essence (Albertus Magnus 2015, 113, 34-6). The faculties are not, indeed, a definition of the soul, insofar as they are not logical parts, like genus (animal) and species (rational). The identity of a totum potestativum is, thus, dynamic, potential, or better: virtual. 'Virtual' indicates, namely, a force (virtus) to develop oneself through one's own powers. But the action of the faculties does not affect the nature of the soul. The action of the faculties happens to the soul as an accident, 
that is, as a contingency that could have been different. The identity of a totum potestativum is, therefore, dynamic: a being is considered from the point of view of its relation with what is outside of it, or different from it. The identity of the soul as a totum potestativum refers to how and what the soul imagines, remembers, desires, loves, understands... Such relations are constitutive of its being as a potential totality, that is, as a totality the identity of which is always defined by its tendency to develop itself through the relation with what is different from it. This kind of identity is, thus, called qualitative, in the sense of relational, and accidental, as far as it includes the contingency of the different relations that a being builds in the different circumstances of its existence in time and space.

Albert calls this type of relational and contingent identity also a qualitative identity, as opposed to a substantial or essential identity. With this distinction, Albert shows that, in these different modes of identity, the individual is always considered as a totality, that is, as a composition of parts that imply relations with each other. Moreover, he emphasises that the so-called individual is always a composition of potentiality and actuality. Therefore, with the distinctions that we will now explore, Albert extends to other modes of identity the dynamic, potential, relational aspects that he has underlined in the identity of the totum potestativum. Far from being an alternative secondary model, the identity that is proper to the whole of powers manifests some characteristics that could be common to other modes of identity, above all in the aspects of relationality and of potentiality.

\subsection{The extension of potentiality and relationality to other models of identity}

Albert exports the characteristics of potentiality and relationality that he finds in the 'non-attributivismus' model of the identity of the human soul to other patterns of identity concerning the human being as a whole, body and soul. We will focus on the essential and on the substantial modes of identity.

\subsubsection{Essential identity}

The essential identity of a being concerns what is part of its essence (Albertus Magnus 2015, 113, 38-41). At first sight, this mode of identity belongs to the 'attributivismus' pattern. But Albert elaborates the mode of essential identity, so as to underline its potentiality and its relationality. He shows, namely, that, under an essential point of view, identity means also totality. Here, Albert deals with the totality that he calls the absolutely first composition of a reality, for instance body 
and soul for a human being. Body stands for what a human being is as a substratum, its quod est, and soul for what gives the body its form as the body of this precise individual (its quo est) (Schneider 1906, 393; Hasse 2008, 236f.). So body and soul are not stricto sensu parts of the definition of a human being, as genus and species, but they have the very logical functions of genus and species as matter and form. The function of matter is, namely, what is indeterminate and receives an identity, whereas the function of form is what gives determination to the compositum.

This definition of identity from an essential point of view applies also to spiritual beings, like the soul. The soul is, indeed, also a totality composed by its parts that cannot be matter and form, because matter is known from its potentiality to be moved and to change (Albertus Magnus 2015, 111, 36-40). As the soul has no matter, it is, therefore, rather constituted by quod est and quo est. Quod est differs from matter as the substrate of a hylemorphic compound differs from the potentiality to receive a form: in the same way as the substratum lies under the potentiality, quod est 'lies under' matter, as its condition of possibility (Albertus Magnus 2015, 111, 47-51; Algazel 1933, 7, 23-5; Gilbertus Porretanus 1847, 1321B; 1966, 202, 86f.; Albertus Magnus 1993b, 272, 50-273, 3). In some way, it is the condition of the possibility to become other than it already is. For this ground potentiality, according to Albert, there is no other definition than what can be predicated to what is: everything that can be attributed to a spiritual substance belongs to quod est as a set of all possibilities. Therefore, the soul is essentially constituted of the very ontological foundation of matter itself, that is, of the possibility to be determined, on the one hand. And, on the other hand, the soul is composed of quo est, that is, of being in the sense of the essence in action. Quo est means the actualisation of the fundamental potentiality that the soul is (Albertus Magnus 2015, 111, 51-9; Boethius 2000b, 187, 26).

Thus, the individualisation of the being of the soul comes from its properties that, in their turn, follow the quod est. Not only does the essential identity of a being include its potentiality to become, through its determination, but also the essential identity of a totality evolves according to its properties, that is according to the determinations that can occur to the substance. Therefore, the essential identity describes a totality that includes the possibility to be determined as the condition of its own identity. And the unity between the principle of potentiality and the principle of actuality is much more important than the unity between matter and form in a hylemorphic compositum. When it comes to the soul, quod est and quo est are, namely, inseparable, whereas the form of a hylemorphic compositum is separable from its matter. Moreover, whereas the form of matter is the form of a part of the compositum, quo est is the form of the whole (Albertus Magnus 2015, 111, 60-8; cf. Boethius 1916, 215, 16-216, 2). Therefore, the essential identity of the soul is relational and dynamic: it relies on the most intimate relationship between the condition of potentiality and the condition of actuality. 


\subsubsection{Substantial identity}

The extension of the notions of potentiality and of relationality inside a totality applies also to the substantial identity of a being. This substantial identity (Albertus Magnus 2015, 113, 41-54), for its part, considers the being of a compositum inasmuch as it is composed. At first sight, this mode of identity belongs also to the 'attributivismus' model. Let us see how Albert elaborates the substantial mode of identity of the human being as a body-soul composition to bring out its potentiality and its relationality. In such a substantial totality, there are, namely, indispensable parts that achieve the potentiality (posse) of the soul as motor of the body and other parts that fulfil the being of the body, insofar as it is moved by the soul. Thus, in this perspective, both parts of the compositum are taken as correlative. In other words, they are considered under the aspect of their mutual relationship as active and passive terms: the soul, inasmuch as it moves the body, and the body, insofar as it is moved by the soul. Not only are the parts correlative, but the whole as well cannot exist without the substantial parts that contribute to the perfection of its substance.

Nevertheless, the parts of the substantial whole do not achieve the perfection of the whole in itself, but only in its parts as considered in themselves (secundum se). The soul, for its part, is the perfection of the whole, whereas its substantial parts can only achieve perfection of the singular parts. In other words, they do not achieve the perfection of the soul in itself. But, in some way, they can be said to achieve the perfection of the soul inasmuch as the soul is the substance of the body and moves it. In the substantial conception of identity, the parts contribute, namely, only to an aspect of the identity of the whole. The parts cannot embrace the identity of the whole. The whole maintains its supremacy upon the parts. Only the upper part can have an influence on the totality in itself (secundum se). The body as such and the soul as such are not affected per se, in their own essence, by the other part of the composition. The relationality of the substantial totality is not reciprocal and total. The parts develop the potentiality of a specific part of the substantial whole.

Therefore, to describe the substantial identity of a compound Albert does not appeal to his distinction about the identity of the soul, that is, between the identity of a spiritual substance and the identity of an active substance. He does not either explicitly refer to the notion of totum potestativum in relation to substantial identity. Nevertheless, he transfers the relational, dynamic and potential conception of the identity of the soul as an active substance to the substantial identity of the human being as a compositum of body and soul. In the perspective of the substantial mode of identity revisited by Albert, each individual is to be considered as a totality that depends on the potentiality of its parts. Each part, depending on 
its hierarchical grade, has a specific relation to the whole. Therefore, substantial identity appears as a relational, dynamic and potential conception of the identity of an individual that includes a variation according to the grades of potentiality, namely the degrees of capacity to achieve the whole or its different parts.

As a conclusion on the first step of this paper, it appears that there is another way of conceiving of the identity in Albert's Euvre that is alternative to the 'attributivismus' model. This pattern is essentially dynamic, relational, orientated towards the potentiality of the individual subject, conceived of as a totality of powers. Albert calls this model totum potestativum, which means that the potentiality of the active subject is achieved through its powers (ibid., 113, 17-19). The second point is that the characteristics of the identity of the totum potestativum apply under certain aspects to the other conceptions of identity. They reveal that the identity of every individual can be considered as a totality that implies relationality between its parts. The conception of those parts depends on the different points of view adopted on the identity of the individual.

Under the aspect of its essence, an individual is, namely, a composition of potentiality and determination: either of matter and form for physical beings, or of quod est and quo est for spiritual beings. Thus also, a spiritual being which is not made up of matter is a totality that is composed of possibility, which is the condition for its being determined by the actualisation of its essence. Under the aspect of its substance, an individual is composed of indispensable parts. The superior ones achieve the potentiality of the soul as a whole, the inferior ones complete the potentiality of the body. They do not separately accomplish the potentiality of the whole. Therefore, Albert extends the main characteristics of the identity model of the totum potestativum, that is, relationality and potentiality, to the other conceptions of identity, namely essential and substantial. He reveals that they all deal with a compound that is considered as a dynamic totality that develops and achieves its own potentiality.

\section{Hierarchy or equality?}

\subsection{Hierarchical relationality}

To develop an alternative model of identity to the 'attributivismus', Albert has recourse to the notion of totum potestativum developed by Boethius in his De divisione (Albertus Magnus 1913, 75; Boethius 1998, 38, 13-40, 1; 40, 25f.; cf. Schneider 1906, 519f.; cf. König-Pralong 2007, 391-7; cf. Hasse 2008, 243f.). On the one hand, the whole of powers is distinct from the integral whole, or quantitative 
whole: for instance the totality of points constituted by a line or the totality of a body constituted by its limbs. On the other hand, the totum potestativum differs from the non-continuous whole in which the parts are ordered to a first principle: the pastor for the flock, the chief for the people or for the army. Lastly, the whole of powers distinguishes itself from the universal whole (Libera 1980, 529-58; 1981, 55-74), for instance the categories of horse or man for all the individuals that they comprehend. The whole of powers, for its part, is constituted and developed by its own powers.

Albert develops two main properties for the soul as totum potestativum. The first concerns the procession order of the faculties from the principle and the second regards the relation of inclusion. The powers to grow, to feel and to understand flow, namely, from the soul, as the principle of life and movement. The first power, the vegetative, is included in the median one, namely the sensitive power, and both of these powers are included in the latter, the intellective one, as the triangle is included in the tetragon.

The second property is relative to the respective power of action of each faculty. All that the lower powers, the vegetative and sensitive ones, can do, the superior power, namely the intellective one, can also do. Moreover, the superior power can do it in an excellent and eminent way. But Albert asserts that this relation is not convertible, in the logical sense, that is, the relation is not reversible: the lower powers cannot do what the upper can.

Let us note at once that, in the tradition of the Latin authors invoked by Albert, the problem of the inclusion of the faculties of the soul and of their powers to act is that this is not reciprocal: $a$ is in $b$ which is, in its turn, in $c$. For its part, $c$ concentrates all the power of action that it receives from $a$ and $b$. Furthermore, $c$ determines in its own way the powers that it receives from $a$ and $b$. But this relation does not function in the opposite way. $A$ and $b$ cannot do what $c$ can do.

The whole of powers is a hierarchy. The whole of powers, in its parts, is so that the first part is potestatively included in the following, or the median one, and the median one in the furthest one, as Aristotle says in the second book De anima (Aristoteles, De anima, lib. 2, cap. 3, 414b28-415a18 in Thomas de Aquino 1984, 87b and cap. 6, 91ab), that the vegetative <power $>$ is in the sensitive one, and the vegetative and the sensitive in the intellectual one, as the triangle is in the tetragone. And, for this reason also, Dionysius (Dionysius Areopagita 2012, 25, 9-11; Dionysius Areopagita 1937, vol. 2, 823f.; cf. Albertus Magnus 1993c, 80, 88-81, 2) and Boethius (Boethius 2000a, 149, 88-150, 91) say that all what the lower power can, the higher power can in a more excellent and eminent way, not the other way around.

(Albertus Magnus 1895, 408b)

In the totality of powers, like the soul, the parts stand in a relation of inclusion of the lower powers in the highest one that possesses and can do more than the lower powers can do. This type of relations does not correspond in any way to a 
relation of reciprocity. In these Boethian and Dionysian perspectives that Albert takes up, the soul is a hierarchical totality without reciprocal relations between its parts. Therefore, to resolve the problem of the full reciprocity of the relations in the soul as a totality of powers, Albert needs another model. He finds it in the eleventh proposition of the Liber de causis.

\subsection{The solution of the Liber de causis for the reciprocal interiority of cause and effect}

At the end of the eleventh proposition of the Liber de causis, the Latin translation (Casteigt forthcoming) gives an example that describes the dynamics of reciprocity in cause and effect. In the example, the anonymous tractate deals with the powers of the soul as well as the first metaphysical principles, in particular Intelligence and Being. The example gradually enumerates how the sensible power of the soul is in the soul and, then, how the soul is in Intelligence, as a universal principle, and Intelligence in Being, as the upper principle, just under the unknowable and ineffable First Cause. The cause is, namely, in its effect on the mode of the effect that receives it.

And indeed, we abbreviate and say that the thing that acts (res agens) upon a thing on the mode of the cause is in it only on the mode according to which its cause is, as the sense $<$ is $>$ in the soul on an animated mode, the soul is in intelligence on an intellective mode, intelligence $<\mathrm{is}>$ in being on an essential mode, the first Being $<\mathrm{is}>$ in Intelligence on an intellective mode, Intelligence $<$ is $>$ in the soul on an animated mode, and the soul $<$ is $>$ in the sense on a sensible mode.

(Liber de causis, prop. XI (XII), in Albertus Magnus 1993a, 124, 78-82)

Unlike the non-reciprocal relations between the parts of the totum potestativum, the characteristic of this description is the reciprocity of the immanence of the cause in its effect, in the ascendant movement, and of the effect in the cause, in the descendant movement. How shall we understand res agens, so that the senses are in the soul on an animated mode and, reciprocally, the soul in the senses on a sensitive mode?

In order to account for this reciprocal immanence, Albert's strategy consists in varying the meanings of 'cause'. The senses are, namely, in the soul on the animated mode that is proper to the soul, inasmuch as they determine and achieve the soul through a sensation in act. Reciprocally, as the substratum that receives this determination, the soul confers its own mode to the senses. So, the senses and the soul are simultaneously causes of each other but each according to a different meaning. The senses, which come after (posterior) the soul, are causes in the meaning of what formally determines and achieves the soul. The soul, which 
precedes (anterior) the senses, is a cause in the meaning of the substratum in which what comes after inheres on an inchoative, that is still indeterminate, mode.

Transferring the example taken out of the Liber de causis to the powers of the soul, each one is in the other one according to a relative rank: anterior, median and posterior grade. The relative order of the powers inside the soul conditions the reciprocity of their relations. The vegetative power of the soul is in the sensitive power on a sensitive mode, and is in the intellective one on an intellective mode. In other words, what is anterior in the development of the soul, as a whole of powers, is determined as a sensation in the senses and as an intellection in the intellect according to an integrative process in which the soul expands its activity. And both the senses and the intellect lie in the vegetative faculty of the soul on a still indeterminate mode that remains as a potentiality for the development of the soul. The senses, in their turn, as the median part of the whole, are in the vegetative power as in their substratum (in the sense of determinable cause) on an indeterminate mode and they are in the intellect on an intellective mode, as a sensation achieved in an intellection. The intellect is, at its turn, in the senses and in the vegetative faculty as in its substratum on an indeterminate mode.

\section{As a conclusion}

Firstly, Albert does not only conceive of the identity of the subject on an 'attributivist' mode that predicates attributes to a substance. He also develops an alternative pattern that he identifies with the Boethian totum potestativum. The features of this model offer a dynamic perspective on identity. They underline the potentiality and the relationality of the individual subject conceived of as a whole that develops itself through its powers.

Secondly, Albert highlights the potentiality and the relationality inherent to other modes of identity, such as the essential and the substantial ones. The identity of the individual is, namely, to be conceived of as a totality composed of potentiality and actuality, or of the fundamental possibility to become and of the determination of this possibility. The model of the totum potestativum emphasises that every individual is a totality that implies different levels of relationality: on the ground level of the condition of determination and reception of this determination, on the level of the first ontological composition of matter and form, on the level of a substance and its properties, or on the level of a whole of powers and its faculties.

Thirdly, the totum potestativum is a hierarchical whole in which the relations are not reciprocal. With this model, Albert cannot account for the equality of the 
parts that entails their reciprocal immanence. But, following a Greek-Arabic-Latin translatio studiorum, that is, a transfer of texts and doctrines from Greece to the Latin medieval world through the Arabic cultural arena, he finds a model for this reciprocity of the relations between the powers of the soul in the eleventh proposition of the Liber de causis. Through a variation of the meanings of 'cause' - as substratum (determinable cause) and as determination (determining cause) - Albert explains that the lower powers of the soul are in the upper ones on the mode of the upper ones, that is as a determination, and that the upper ones are simultaneously in the lower ones, as in their substratum, on an indeterminate mode.

Albert the Great's Euvre offers, therefore, several models to conceive of the identity of a subject. They remain incompatible points of view on the same individual. And they describe the identity of the subject under different perspectives and dynamics: the powers of the soul are consequences of the spiritual substance, according to the 'attributivismus' model, whereas they are substantial parts of the soul considered as a whole of powers, in particular. But Albert highlights, in each of the conceptions of identity that he displays, the relationality and the potentiality that each point of view on the identity of an individual implies. From a historical, geographical and, more generally, cultural point of view, it follows that the Albertian conception of the subject, as a completely relational, that is reciprocal, totality, requires not only a Greek-Latin translatio studiorum, but a more complex detour: from Greek through Arabic to Latin texts, cultures and ways of thinking.

\section{References}

\section{Sources}

Albertus Magnus. 1913. Commentarii in librum Boethii de divisione. Ed. P. M. de Loe. Bonnae: Sumptibus P. Hanstein.

Albertus Magnus. 1968. De anima. Eds. C. Stroick, B. Geyer, Ed. Col. VII/1. Münster: Aschendorff.

Albertus Magnus. 1993a. De causis et processu universitatis a prima causa. Ed. W. Fauser, Ed. Col. XVII/2. Münster: Aschendorff.

Albertus Magnus. 2008. De homine. Eds. H. Anzulewicz, J. R. Söder, Ed. Col. XXVII/2. Münster: Aschendorff.

Albertus Magnus. 1993b. 'Quaestio de quiditate et esse.' In Quaestiones, eds. A. Fries, W. Kübel, H. Anzulewicz, Ed. Col. XXV/2, Münster: Aschendorff. 271-80.

Albertus Magnus. 1895. Summa theologiae. Secunda pars, q. 1-67. Ed. A. Borgnet, Ed. Par. XXXII. Parisiis: Vivès.

Albertus Magnus. 1993c. Super Dionysium De caelesti hierarchia. Eds. P. Simon, W. Kübel, Ed. Col. XXXVI/1. Münster: Aschendorff. 
Albertus Magnus. 2015. Super I librum Sententiarum: Distinctiones 1-3. Ed. M. Burger,

Ed. Col. XXIX/1. Münster: Aschendorff.

Alexander de Hales. 1960. Glossa in quatuor libros Sententiarum Petri Lombardi. Nunc primum edita studio et cura P. P. Collegii S. Bonaventurae, T. 1-4. Florentiae: Quaracchi.

Algazel. 1933. Algazel's Metaphysics. Ed. J. T. Muckle. Toronto: St Michaels College.

Augustinus Hipponensis. 1968. De trinitate. Ed. W. J. Mountain, auxiliante F. Glorie,

CCSL L. Turnhout: Brepols.

Bernardus Claraevallensis. 1957. 'Sermones super canticum canticorum.' In S. Bernardi Opera, vol. 1, eds. J. Leclercq, C. H. Talbot, H. M. Rochais, Romae: Editiones Cistercienses.

Boethius, Anicius Manlius Severinus. 2000a. De consolatione Philosophiae: Opuscula Theologica. Ed. C. Moreschini. Monachii: K. G. Saur.

Boethius, Anicius Manlius Severinus. 1998. De divisione liber. Critical edition, translation, prolegomena and commentary by J. Magee. Philosophia antiqua 87. Leiden/Boston/Köln: Brill.

Boethius, Anicius Manlius Severinus. 1916. In Isagogen Porphyrii Commenta. Eds. G. Schepss,

S. Brandt, CSEL XLVIII. Vindobonae: F. Tempsky/Lipsiae: G Freytag.

Boethius, Anicius Manlius Severinus. 1847. Liber de divisione. Ed. J.-P. Migne, PL LXIV. Parisiis. 875-92.

Boethius, Anicius Manlius Severinus. 2000b. 'Quomodo substantiae in eo quod sint bonae sint cum non sint substantialia bona.' In De consolatione Philosophiae: Opuscula Theologica, ed. C. Moreschini, Monachii: K. G. Saur. 186-94.

Dionysius Areopagita. 2012. De coelesti hierarchia, De ecclesiastica hierarchia, De mystica theologia, Epistulae. Eds. G. Heil, A. M. Ritter. Corpus Dionysiacum II, PTS LXVII. Berlin: Walter de Gruyter (2. überarbeitete Auflage).

Dionysius Areopagita. 1937. Recueil donnant l'ensemble des traductions Latines des ouvrages attribués au Denys de l'Aréopage. Ed. P. Chevallier. Dionysiaca, tomes 1-2. Bruges: Desclée de Brouwer et Cie.

Gilbertus Porretanus. 1966. 'Commentaria in librum Boethii De hebdomadibus.' In The commentaries on Boethius by Gilbert of Poitiers, ed. N. M. Häring, Toronto: Pontifical Institute of Mediaeval Studies.

Gilbertus Porretanus. 1847. Commentaria in librum quomodo substantiae bonae sint. PL LXIV. Parisiis. 1314-34.

Petrus Lombardus. 1981. Sententiae in IV Libri distinctae. Ed. tertia, Spicilegium Bonaventurianum V, tomus 1: Prolegomena, Liber I et II, 1971; tomus 2: Liber III et IV, Grottaferrata, ad Claras Aquas: Collegii S. Bonaventurae.

Pseudo-Augustinus. 1845. 'De spiritu et anima.' In Alcherus Claraevallensis. PL XL, Parisiis. 779-832.

Thomas de Aquino. 1984. Sentencia libri de anima. Ed. Leonina XLV/1. Romae: Commissio Leonina/Paris: Librairie philosophique Joseph Vrin.

\section{Secondary Literature}

Anzulewicz, Henryk. 2000. 'Albertus Magnus - Der Denker des Ganzen’, Wort und Anwort 41. 148-54.

Anzulewicz, Henryk. 2012. 'Anthropology: the concept of man in Albert the Great.' In $A$ Companion to Albert the Great: Theology, Philosophy, and the Sciences. Ed. I. M. Resnick, Leiden/Boston: Brill. 325-46. 
Casteigt, Julie. Forthcoming. 'L'unité de la cause et de son effet comme immanence réciproque: la proposition XI du Liber de causis commentée par Albert le Grand.' In Les Éléments de théologie et le Livre des causes du $V^{\mathrm{e}}$ au XVI ${ }^{\mathrm{e}}$ siècles, vol. 3: Causes - causalités / Être-vie-pensée // The Elements of Theology and the Book on Causes from the 5th to the 16th Centuries, vol. 3: Causes and Causality - Being-Life-Intellect, eds. D. Calma, M. Geoffroy, Leiden: Brill.

Hasse, Dag Nikolaus. 2008. 'The Early Albertus Magnus and his Arabic Sources on the Theory of the Soul', Vivarium 46. 232-52.

Hellmeier, Paul Dominikus. 2011. Anima et intellectus: Albertus Magnus und Thomas von Aquin über Seele und Intellekt des Menschen. Münster: Aschendorff.

König-Pralong, Catherine. 2007. 'Figures fantômes de Platon dans la philosophie scolastique médiévale’, Freiburger Zeitschrift für Philosophie und Theologie 54 (3). 386-406.

Krause, Katia; Anzulewicz, Henryk. 2017. 'Appropriating Traditions of Totality: Reality as a Whole in Albert the Great.' In Regards sur les traditions philosophiques (XII'-XIV siècles), eds. Z. Kaluza, D. Calma, Leuven: Leuven University Press. 99-125.

Künzle, Pius. 1956. Das Verhältnis der Seele zu ihren Potenzen: Problemgeschichtliche Untersuchungen von Augustinus bis und mit Thomas von Aquin. Freiburg (Schweiz): Universität Verlag.

Libera, Alain de. 2007. Archéologie du Sujet: Naissance du sujet, I. Paris: Librairie philosophique Joseph Vrin.

Libera, Alain de. 1980. 'Logique et existence selon saint Albert le Grand', Archives de Philosophie 43.529-58.

Libera, Alain de. 1981. 'Théorie des universaux et réalisme logique chez Albert le Grand', Revue des Sciences philosophiques et théologiques 65. 55-74.

Mahoney, Edward Patrick. 1980. 'Albert the Great and the Studio Patavino in the Late Fifteenth and Early Sixteenth Centuries.' In Albertus Magnus and the Sciences: Commemorative Essays 1980, ed. J. A. Weisheipl, Toronto: Pontifical Institute of Mediaeval Studies. 537-63.

Müller, Jörn. 2009. 'Die Seele als Seins- und Tätigkeitsprinzip des menschlichen Lebens nach Averroes, Albertus Magnus und Thomas von Aquin.' In Das Leben: Historischsystematische Studien zur Geschichte eines Begriffs, vol. 1, eds. P. Bahr, S. Schaede, Tübingen: Mohr Siebeck. 194-203.

Park, Katharine. 1980. 'Albert's Influence on Late Medieval Psychology.' In Albertus Magnus and the Sciences: Commemorative Essays 1980, ed. J. A. Weisheipl, Toronto: Pontifical Institute of Mediaeval Studies. 501-35.

Schneider, Arthur Carl August. 1903; 1906. Die Psychologie Alberts des Großen nach den Quellen dargestellt: Beiträge zur Geschichte der Philosophie des Mittelalters, Bd. IV, Hefte 5-6, 2 vols. Münster: Aschendorff. 
